\title{
PARTISIPASI PEMILIH DALAM PEMILIHAN UMUM PRESIDEN DAN WAKIL PRESIDEN TAHUN 2019 DI KOTA MATARAM
}

\author{
Ayatullah Hadi ${ }^{1}$, Rahmad Hidayat ${ }^{2}$, Lalu Nanang Alwi ${ }^{3}$ \\ ${ }^{1}$ Prodi Ilmu Pemerintahan, FISIP, Universitas Muhammadiyah Mataram \\ ${ }^{2}$ Prodi Administrasi Publik, FISIP, Universitas Muhammadiyah Mataram \\ ${ }^{3}$ Prodi Administrasi Publik, FISIP, Universitas Muhammadiyah Mataram
}

\begin{abstract}
Elections are a means of democratic experience. It can be said that there is no democracy without elections. However, elections are not an objective, but as a means of electing parliamentarians and executive leaders at the central and regional levels. In the concurrent elections on 17 April 2019 which were held throughout Indonesia, including the Election Commission of Mataram City which had recorded the number of DPT in Mataram City amounted to 278,358. This study uses political culture theory (Gaffar 2004), types of political culture (Davies and Lewis, 1971), voter participation (McClosky in Miriam Budiardjo 2008), as a knife for analysis and as an instrument for researchers to examine in depth about voter participation in presidential elections and vice president in 2019 in the city of Mataram. The research methodology used is a qualitative approach with a descriptive analysis method. Descriptive analysis methods are used to get a systematic, factual, and accurate picture of the facts, the characteristics and the relationship between the phenomena under investigation.The conclusion of this study is the number of people participating in Mataram City up to 222,687 voters, and looking at the results of research between active voter participation models and apathetic voters, the people of Mataram are included in active voters with $60 \%$ while apathetic voters are $40 \%$.
\end{abstract}

Keywords: General Election, Voter Participation, Active Voters and Apathetic Voters

\begin{abstract}
Abstrak
Pemilihan umum merupakan sarana pengalaman demokrasi. Dapat dikatakan tidak ada demokrasi tanpa pemilu. Walaupun begitu, pemilihan umum bukanlah tujuan, akan tetapi sebagai sarana untuk memilih anggota parlemen dan pemimpin eksekutif dipusat dan daerah. Dalam pemilu serentak tanggal 17 April 2019 yang diselenggarakan diseluruh Indonesia, termasuk KPUD Kota Mataram yang telah mencatat jumlah DPT di Kota Mataram berjumlah 278.358. Penelitian ini mengguakan teori budaya politik (Gaffar 2004), tipe budaya politik (Davies dan Lewis, 1971), partisipasi pemilih (McClosky dalam Miriam Budiardjo 2008), sebagai pisau analisa dan sebagai instrument peneliti untuk mengkaji secara mendalam tentang partisipasi pemilih dalam pemilihan umum presiden dan wakil presiden tahun 2019 di Kota Mataram. Metodelogi penelitian yang dipakai adalah pendekatan kualitatif dengan metode analisis diskriftif. Metode deskriftif analisis digunakan untuk mendapatkan gambaran secara sistematis, factual, dan akurat mengenai fakta-fakta, sifat-sifat serta hubungan antara fenomena yang sedang diselidiki. Kesimpulan dari penelitian ini adalah jumlah partisipasi masyarakat Kota Mataram sampai pada angka 222.687 pemilih, dan melihat hasil dari penelitian antara model partisipasi pemilih aktif dan pemilih apatis, masyarakat kota Mataram termasuk kedalam pemilih berpatisipasi aktif dengan jumlah $60 \%$ sedangkan pemilih apatis berjumlah $40 \%$.
\end{abstract}

Kata Kunci: Pemilihan Umum, Partisipasi Pemilih, Pemilih Aktif dan Pemilih Apatis

\section{PENDAHULUAN}

Indonesia merupakan negara yang menganut sistem demokrasi, yang kekuasaan pemerintahannya berasal dari rakyat. Pada pasal 1 ayat 2 Undang-Undang Dasar Tahun 1945 dinyatakan bahwa kedaulatan berada ditangan 
rakyat dan dilaksanakan menurut undang-undang dasar, untuk melaksanakan kedaulatan rakyat, maka dilakukan pemilihan umum. Pemilihan umum (berikutnya di singkat Pemilu) diartikan sebagai proses pemungutan suara dimana semua warga negara mempunyai hak yang sama untuk memilih dan dipilih menjadi pemimpin.

Pemilu merupakan sarana pengamalan demokrasi. Dapat dikatakan tidak ada demokrasi tanpa pemilu. Walaupun begitu, pemilu bukanlah tujuan, akan tetapi sebagai sarana untuk memilih anggota parlemen dan pemimpin eksekutif dipusat dan daerah. Adapun tujuan kita berbangsa antara lain untuk memajukan kesejahteraan umum dan mencerdaskan kehidupan.

Masyarakat memiliki peran yang sangat penting dalam penyelenggaraan demokrasi seperti halnya pemilu. Oleh karenanya, masyarakat tidak dapat dipisahkan dengan pemilu karena merupakan satu kesatuan yang utuh menjadi faktor utama dan penentu suksesnya sebuah pelaksanaan pemilu.

Sebuah pelajaran berharga kepada masyarakat mengenai makna dan arti dari sebuah pemilu itu sendiri sehingga masyarakat tidak terperosok kedalam kesalahan pada saat memilih kandidat pemilu. Pengguna hak suara sangat menentukan arah dan masa depan sebuah Negara yang menganut sebuah demokrasi, dimana seorang pemimpin merupakan perwujudan aspirasi masyarakat.

Pemilu tersebut mempunyai makna penting bagi berjalannya demokrasi, dimana setiap warga negara yang telah dianggap dewasa dan memenuhi persyaratan menurut undangundang, dapat memilih pemimpin pemerintahan. Harapan rakyat akan perbaikan negeri ini akan dapat terwujud apabila pemilu dapat menghasilkan pemimpin negara yang mempunyai kompetensi, kapasitas, aspiratif dan mempunyai komitmen dalam mensejahterakan rakyat. Oleh karena itu, seluruh elemen bangsa perlu ikut serta mensukseskan agar mencapai hasil yang optimal. Menurut Andi Faisal (2016), Sebagai dari upaya konsolidasi demokrasi yang semakin kuat, maka perlu dicermati lima indikator pemilu yang berkualitasebagai berikut :

Pertama, pemilu berkualitas menuntut penghapusan budaya politik transaksional atau money politik. Adanya transaksi seperti ini menyebabkan kualitas calon yang tidak dipertimbangkan pemilih sehingga pemilih terbiasa untuk memilih seorang calon berdasarkan harga atau berapa nominal yang didapatkan. Idealnya, masyarakat memilih berdasarkan penilaian yang obyektif sehingga calon tidak perlu mengeluarkan uang untuk meyakinkan pemilihnya, sehingga akan menghasilkan seorang pemimpin yang memiliki legitimasi dan wibawa yang kuat.

Kedua, pemilu berkualitas membutuhkan perbaikan pendataan pemilih. Tingginya angka golput dalam pemilu, ternyata bukan hanya karena masyarakat tidak mau menggunakan hak pilihnya. Namun kekacauan dan ketidakberesan dalam pendataan pemilih membuat banyak masyarakat yang tidak mendapatkan kartu pemilih walaupun mempunyai hak untuk memilih.

Ketiga, pemilu yang berkualitas ditandai dengan meningkatnya partisipasi pemilih. Harapannya, terhapusnya apatisme pemilih terhadap proses dan hasil pemilu karena dianggap pemilih hanya merupakan angka-angka pemenang dari pemilu ke pemilu, usai pemilu seringkali terabaikan dalam proses pembuatan kebijakan. Hal-hal ini tentu tidak baik karena apatisme masyarakat atas lembaga-lembaga demokrasi menjadi faktor penghambat bagi upaya konsulidasi demokrasi.

Keempat, pemilu diselenggarakan oleh Komisi Pemilihan Umuum (KPU) dan Badan Pengawas Pemilihan Umum (Bawaslu) yang memiliki integritas, kapabilitas dan akuntabilitas serta yang tidak kalah penting independen. Disebutkan dalam Undang-Undang Nomor 15 Tahun 2011 tentang Penyelenggara Pemilu bahwa penyelenggaraan pemilu yang berkualitas diperlukan sebagai sarana untuk mewujudkan kedaulatan rakyat dalam pemerintahan negara yang demokratis berdasarkan Pancasila dan Undang-Undang Dasar Negara Republik Indonesia Tahun 1945.

Kelima, pemilu berkualitas mensyaratkan penyelenggaran pemilu sesuai dengan asas jujur, adil, tertib, keterbukaan, proporsionalitas, profesionalitas, akuntabilitas, efisiensi, dan efektivitas. Penyelenggara pemilu harus adil, yaitu adil dalam aturan main dan memberi kesempatan yang sama kepada semua pihak yang terlibat. Pemilu merupakan momentum bagi 
rakyat Indonesia untuk membuka lembaran baru sejarah demokrasi Indonesia. Demi terlaksananya pemilu yang berkualitas, peningkatan kinerja penyelenggara pemilu harus diperbaiki dan ditingkatkan, bukan hanya terkait dengan kinerja teknis penyelenggaraan, namun juga dalam hal penumbuhan kesadaran tentang pentingnya partisipasi masyarakat dalam penyelenggaraan pemilu.

Namun adanya pelanggaran yang dilakukan oleh beberapa pihak seperti politisi, contoh kasus Muhammad Ali Akbar yang merupakan Calon Legislatif (Caleg) DPRD Kabupaten Lombok Timur Dapil I dari Partai Keadilan Sejahtera (PKS) Yang terjaring Operasi Tangkap Tangan (OTT) oleh masyaraka dan Pengawas Tempat Pemungutan Suara (PTPS), karena melakukan money politic dengan bagibagi uang Rp 25.000.(tribunwow.com,16/4/2019). Dengan adanya kasus seperti ini tentu akan mencoreng nilai dari demokrasi, yang tentunya dapat menyebabkan adanya kebiasaan dari pemberi dan penerima pasca adanya pemilu berikutnya. Kasus ini juga dapat menyebabkan terganggunya proses konsolidasi demokrasi yang semakin kuat dengan indikator yang disebutkan diatas.

Khusus di Kota Mataram sendiri, dalam pemilihan umum Presiden dan Wakil Presiden tahun 2014, Di dalam daftar pemilih tetap (DPT) Kota Mataram tercatat sebanyak 292.215 pemilih, DPT tambahan sebanyak 665 orang, Daftar Pemilih Khusus (DPK) 984 orang, dan DPK tambahan sebanyak 9.667 orang, sehingga total pemilih di Kota Mataram sebanyak 303.535 pemilih. Rapat pleno yang diselenggarakan di Hotel Lombok Garden, serta terperoleh 215.388 jumlah suara sah, sementara jumlah suara tidak sah 1.455 suara. Melihat jumlah ini, tingkat partisipasi masyarakat Kota Mataram dalam pemilu presiden dan wakil prsiden tahun 2014 hanya 71 persen. (Kompas.com,17/07/2014).

Dalam pemilu serentak tanggal 17 April 2019 yang diselenggarakan diseluruh Indonesia, KPUD Kota Mataram mencatat jumlah DPT di Kota Mataram berjumlah 278.358 DPT. Pada pemilu serentak tahun 2019 ini KPUD Kota Mataram mercatat jumlah partisipasi pemilih pada pemilihan presiden dan wakil presiden, DPDRI, DPRRI, DPRD Provinsi, DPRD Kabupaten hingga 80\% dari target Nasional $77 \%$.
(antaraNTB, 03/05/2019). Maka dapat disimpulkan bahwa terjadi peningkatan partisipasidari masyarakat dalam mengikuti pemilu dari tahun 2014 hanya $71 \%$ menjadi $80 \%$ ditahun 2019.

Salah satu di antara elemen dan indikator yang paling mendasar dari keberhasilan dan kualitas pelaksanaan penyelenggaraan pemilu yang demokratis adalah adanya keterlibatan masyarakat secara aktif dalam proses berjalannya tahapan-tahapan pemilu, khususnya dalam hal pengawasan atau pemantauan proses pemilu. Peran dan partisipasi masyarakat sipil dalam mengawasi atau memantau jalannya proses kontestasi demokrasi merupakan hal yang sangat penting.

Menurut Miriam Budiardjo (2009), partisipasi politik adalah kegiatan seseorang atau sekelompok orang untuk ikut secara aktif dalam kehidupan politik, antara lain dengan jalan memilih pimpinan negara dan secara langsung atau tidak langsung memengaruhi kebijakan pemerintah (public policy). Kegiatan itu mencakup tindakan seperti memberikan suara dalam pemilihan umum, menghadiri rapat umum, mengadakan hubungan (contacting) atau lobbying dengan pejabat pemerintah atau anggota parlemen, menjadi anggota partai atau salah satu gerakan sosial dengan direct actionnya, dan sebagainya.

Tetapi perlu diingat bahwa, Pemilu merupakan wadah pergantian kekuasaan secara legal. Seperti pembahasan di atas, proses Pemilu merupakan proses yang sangat rentan terjadinya penggiringan opini oleh elit politik bahkan terjadinya politik uang. Fenoma yang terjadi menjelang pemilu mempengaruhi berbagai model partisipasi masyarakat saat terlibat dalam pemungutan suara. Model partisipasi tersebut misalnya dapat dipengaruhi oleh berbagai peristiwa yang terjadi di tengah masyarakat termasuk struktur sosial serta kondisi ekonomi, isu agama, rasial dan opini publik.

Tujuan dari tulisan ini yaitu untuk mengetahui bagaimana model partisipasi pemilih di Kota Mataram pada pemilihan umum presiden dan wakil presiden tahun 2019.

\section{METODE}

Dalam penelitian ini penulis menggunakan pendekatan kualitatif dengan 
metode analisis deskriftif analisis. Metode deskriftif analisis digunakan untuk mendapatkan gambaran secara sistematis, factual dan akurat mengenai fakta-fakta, sifat-sifat serta hubungan antara fenomena yang sedang diselidiki.

\section{Lokasi Penelitian}

Dalam penelitian ini penulis melakukan penelitian di wilayah Kota Mataram dan penelitian ini dilaksanakan pada bulan agustus 2019.

\section{Sumber Data}

Sumber data primer yang digunakan dalam penelitian ini meliputi:

\section{TABEL 3.1}

\section{Sumber Data Primer}

Pengumpulan data dimaksud untuk memperoleh bahan-bahan yang relevan dan akurat. Untuk mengumpulkan data dalam penelitian ini, teknik yang dilakukan adalah :
a. Teknik observasi (pengamatan)
b. Wawancara
c. Dokumentasi

\section{Teknik Analisis Data}

Dalam penelitian ini teknik analisis data adalah teknik kualitatif, dengan mengikuti alur kegiatan miles dan humberman (1984) dalam sugiyono, 2013 : 246-252). Yang terdiri dari beberapa tahap, yaitu :

1. Reduksi Data

2. Penyajian data (data display)

\begin{tabular}{|c|c|c|c|c|}
\hline $\begin{array}{l}\mathbf{N} \\
\mathbf{0}\end{array}$ & $\begin{array}{l}\text { Naras } \\
\text { umber }\end{array}$ & $\begin{array}{l}\text { Jenis } \\
\text { Data }\end{array}$ & $\begin{array}{c}\text { Meto } \\
\text { de }\end{array}$ & Jumlah \\
\hline 1. & $\begin{array}{c}\text { Nelaya } \\
\mathrm{n}\end{array}$ & $\begin{array}{l}\text { Partisipas } \\
\text { i Nelayan }\end{array}$ & $\begin{array}{c}\text { Waw } \\
\text { ancar } \\
\text { a }\end{array}$ & 2 \\
\hline 2. & $\begin{array}{l}\text { Wiras } \\
\text { wasta }\end{array}$ & $\begin{array}{c}\text { Partisipas } \\
\text { i } \\
\text { Wiraswas } \\
\text { ta }\end{array}$ & $\begin{array}{c}\text { Waw } \\
\text { ancar } \\
\text { a }\end{array}$ & 3 \\
\hline 3. & $\begin{array}{l}\text { Pemili } \\
\text { h } \\
\text { Pemul } \\
\text { a }\end{array}$ & $\begin{array}{c}\text { Partisipas } \\
\text { i Pemilih } \\
\text { Pemula }\end{array}$ & $\begin{array}{c}\text { Waw } \\
\text { ancar } \\
\text { a }\end{array}$ & 3 \\
\hline 4. & $\begin{array}{l}\text { Akade } \\
\text { misi }\end{array}$ & $\begin{array}{c}\text { Partisipas } \\
\text { i } \\
\text { Akademi } \\
\text { si }\end{array}$ & $\begin{array}{c}\text { Waw } \\
\text { ancar } \\
\text { a }\end{array}$ & 2 \\
\hline
\end{tabular}

(verification/conclution drowing)

\section{HASIL DAN PEMBAHASAN}

\section{Model Partisipasi Pemilih Dalam}

Pemilihan Umum Presiden dan Wakil Presiden Tahun 2019 Di Kota Mataram

Masyarakat Kota Mataram memiliki hak yang sama dalam pelaksanaan pemilu baik secara langsung ataupun tidak langsung, bahkan dalam proses pembentukan kebijakan umum. Namun dalam konteks penelitian kali ini, peneliti akan menggunakan dua model partisipasi pemilih, antaranya partisipasi aktif dan partisipasi apatis.

Partisipasi merupakan salah satu aspek penting dalam demokrasi. Partisipasi politik warga masyarakat dalam kegiatan-kegiatan

Data sekunder adalah sumber data yang dikutip dari sumber lain dalam bentuk dokumen seperti literature, brosur dan karangan para ahli yang dianggap mempunyai hubungan dengan masalah yang diteliti serta diperoleh dari proses belajar mengajar.

\section{Teknik Pemilihan Informan}

Dalam penelitian ini, penulis menggunakan purposive sampling, yaitu metode pengambilan sampel yang di pilih dengan cermat sehingga relevan dengan struktur penelitian, dimana pengambilan sampel dengan mengambil sampel orang-orang yang dipilih oleh penulis (Djarwanto : 1998 : 34)

\section{Teknik Pengumpulan Data}

politik baik yang bersifat aktif maupun apatis guna mempengaruhi kebijakan yang dikeluarkan pemerintah.

\section{a. Partisipasi Aktif}

Apabila seseorang memiliki kesadaran politik yang tinggi dan kepercayaan kepada pemerintah tinggi, maka partisipasi politik seseorang ini cenderung aktif. Dengan demikian pemerintah bersama KPU harus bekerja sama dalam melakukan sosialisasi dikalangan masyarakat mengenai kesadaran dalam memilih pada pemilihan umum.

\section{1) Tingginya Kesadaran Politik Pemilih di Kota Mataram}

Kesadaran politik sangat berhubungan erat dengan partisipasi politik masyarakat. Ada dua bentuk partisipasi politik yang berkaitan 
dengan momen pemilu yaitu, ikut serta dalam kampanye pemilu dan memberikan suara dalam pemilihan umum. Kesadaran politik adalah kesadaran akan hak dan kewajiban sebagai warga Negara. Dimana masyarakat ikut bagian dalam menentukan arah Negara sebagai bentuk dari demokrasi yang sedang berlansung.

Tingkat kesadaran politik diartikan sebagai tanda bahwa masyarakat menaruh perhatian terhadap masalah bernegara. Selain sadar akan posisinya, masyarakat juga akan menaruh perhatian terhadap proses-proses politik dan pemerintahan yang berlangsung. Perhatian tersebut seperti dengan mengikuti perkembangan informasi politik dan pemerintahan terkini atau bahkan terlibat langsung dalam proses tersebut. Partisipasi politik yang dilandasi oleh kesadaran politik akan menghasilkan sesuatu yang baik dan sesuai dengan aspirasi yang bersangkutan.

Adapun hasil wawancara dengan salah satu akademisi, yakni saudara Jaya Kusuma, mengatakan :

"Seseorang harus memiliki kesadaran politik, kesadaran politik akan melahirkan pemimpin-pemimpin yang memiliki kapabilitas yang tinggi, selain itu kesadaran politik akan menciptakan kehidupan demokrasi yang lebih berkarakter dan berintegritas (hasil wawancara dengan Jaya Kusuma tanggal 12 agustus 2019)”.

Berdasarkan hasil wawancara tersebut, kesadaran politik menjadi salah satu instrument untuk memilih pemimpin secara selektif. Selain itu kesadaran politik akan akan menciptakan kehidupan demokrasi yang lebih sehat, berkualitas, berkarakter dan berintegritas. Kesadaran politik terbentuk karena kesadaran terhadap kehidupan berbangsa dan bernegara agar menjadi lebih baik. Selain itu, kesadaran politik biasanya terbentuk dari pendidikan politik yang kuat dan mengakar melalui proses sosialisasi politik.

Hal ini senada dengan hasil wawancara dengan salah seoarang wiraswasta yakni, Jahman mengatakan :

"Saya berpartisipasi dalam pilpres 2019 karena saya menaruh harapan pada calon. Saya cenderung akan memilih pemimpin yang mengerti dan paham akan kebutuhan profesi saya sebagai wiraswasta yang kemudian saya sesuaikan denga visi-misi dan program-program kerja yang akan dijalankan oleh kandidat tersebut (Hasil wawancara dengan Jahman tanggal 12 Agustus 2019)".

Berdasarkan hasil wawancara dengan ketiga narasumber tersebut maka kesadaran politik bisa dipengaruhi oleh kesadaran dalam kehidupan berbangsa dan kesadaran individualis yang berkaitan dengan profesi dari seseorang itu sendiri. Kesadaran pemilih juga di pengaruhi oleh media sosial sebagai media kampanye dari masing-masing calon. Dimana media sosial sekarang mulai berubah fungsi sebagai lahan pemenangan bagi seseorang yang sedang bergelut dalam bidang politik.

Karena kesadaran politik bisa terbentuk karena kesadaran seseorang akan profesi yang di gelutinya. Seseorang akan cenderung memilih pemimpin yang mengerti dan paham akan kebutuhan sesuai dengan profesinya. Kesadaran politik jenis ini bisanya dilihat dari visi-misi serta program-program kerja yang akan dilaksanakan atau di jalankan oleh kandidat-kandiat pemimpin. Jika visi-misi dan program kerja dari kandidat pemimpin sesuai dengan apa yang di khendaki seseorang dengan profesinya, maka dengan sendirinya ia akan memilih kandidat pemimpin tersebut.

Selain itu kesadaran politik akan terbentuk karena melihat situasi dan kondisi dari lingkungan sekitar yang tak kunjung mengarah pada kualitas hidup yang lebih baik. Hal ini yang mendorong seseorang untuk sadar serta aktif dan selektif dalam memilih calon pemimpin yang memiliki kapabilitas serta berfikir visioner.

Di kota Mataram, kesadaran politik masyarakat yang cenderung tinggi disebabkan oleh faktor kesadaran akan kepentingan bermasyarakat, sedangkan secara individualis kesadaran politik yang cenderung tinggi di pengaruhi oleh kesadaran akan profesi yang dijalani agar kualitas hidup individu tesebut menjadi lebih baik. Kesadaran politik yang tinggi lahir dari kalangan pemilih yang strata sosialnya akademisi dan juga pemilih pemula, sedangkan kesadaran politik yang tinggi secara individualis biasanya lebih condong kepada masyarakat yang berstrata sosial nelayan, wiraswasta dan jenis profesi lainnya. 
2) Tingginya Kepercayaan Masyarakat Kota Mataram Kepada Pemerintah

Tingginya tingkat kepercayaan

masyarakat merupakan indikator yang menunjukkan dukungan masyarakat terhadap kebijakan serta program-program pembangunan yang dilakukan pemerintah. Tingkat kepercayaan masyarakat yang tinggi kepada pemerintah menunjukkan bahwa masyarakat memandang pemerintah sudah resoinsif dan dapat di andalkan dalam hal memberikan perlindungan dan pelayanan kepada masyarakat.

Hal ini menunjukkan kebijakan pemerintah selama ini seperti akselarasi pembangunan insfrastruktur, kebijakan subsidi yang tepat sasaran, serta penguatan desentralisasi fiksal untuk membangun desa dan daerah tertinggal lainnya telah dirasakan manfaatnya oleh masyarakat. Tingginya kepercayaan kepada pemerintah mampu mendorong potensi kepatuhan dan partisipasi masyarakat dalam pelaksanaan kebijakan maupun pada pemilu.

Adapun hasil wawancara dengan seorang wiraswasta, Ahmad Fatoni mengatakan:

"Tingkat kepercayaan saya kepada pemerintah di dasarkan pada trak record dari pemimpin itu sendiri. Sebab trak record akan menunjukkan prestasi-prestasi dari pemimpin itu sendiri. Trak record menjadi acuan untuk meningkatkan kepercayaan dari pemimpin itu sendiri (Hasil wawancara dengan Ahmad Fatoni tanggal 13 Agustus 2019)."

Berdasarkan ketiga hasil wawancara diatas, trak record dan hasil pemilu sangat mempengaruhi tingi rendahnya kepercayaan masyarakat terhadap pemerintah. Trak record dapat dilihat dari prestasi-presati yang telah diraih oleh seorang pemimpin selama ia berkarir dalam bidang politik. Trak record biasanya diukur dari keberhasilan seseorang dalam menjalankan program-program yang menyentuk lapisan masyarakat lapisan menengah ke bawah, trak record tersebut dapat berupa gerakangerakan pemberdayaan kepada masyrakat serta merialisasikan aspirasi dari masyarakat itu sendiri.

Masyarakat Mataram pada umumnya menaruh harapan besar kepada presiden sebagai pemegang kekuasaan tertinggi yang memberikan kebijakan yang nantinya akan mempengaruhi pola hidup masyarakat. Pemilihan Presiden harus di perhatikan dengan baik dan selektif, karena presiden merupakan pemegang legitimasi kekuasaan tertinggi disebuah Negara. Selain itu, kebijakan-kebijakan daerah kadang harus diseusaikan dengan kebijakan pemerintah pusat yakani Presiden. Selain itu porgam-program kerja dikendalikan oleh pemerintah pusat sedangkan pemerintah daerah hanyalah sebagai ujung tombak untuk merealisasikan programprogram kerja tersebut.

\section{b. Partisipasi Apatis}

Demokrasi tidak akan berjalan tanpa partisipasi warga yang kritis. Apatisme publik adalah gejala, diman warga Negara menjadi tidak peduli pada hal-hal yang terkait dengan kehidupan bersama. Artinya, warga Negara tidak lagi kritis dan partisatif di dalam kehidupan bersama. Demokrasipun tinggal slogan yang mengambang tanpa realitas, sikap apatis seringkali di kaitkan dengan problem-promblem yang terjadi di masyarakat baik idiologi, politik, ekonomi, sosbud, militer, pendidikan dan lainlain.

Apatis terhadap pemilu bisa jadi di akibatkan karena adanya ketidak yakinan masyarakat terhadap adanya perubahan, sikap ini justru membuat pihak yang tidak layak sebagai presiden menjadi presiden. Sehingga akan mengukuhkan kepemimpinan yang merugikan, kondisi ini melahirkan individualis dan pasif. Bisa jadi masyarakat memandang elit politik tidak mengalami perubahan yang jelas, di sebabkan karena masyarakat sering menjadi korban politik pemerintah yang sedang berkuasa. Partisipasi apatis muncul karena rendahnya kesadaran politik masyarakat serta rendahnya kepercayaan masyarakat terhadap pemerintah. Kedua indikator ini dinilai dapat memberikan dampak negative terhadap kehidupan bernegara.

\section{1) Kesadaran Politik Rendah}

Kesadaran akan hak dan kewajiban sebagai warga Negara yang menyangkut tentang lingkungan masyarakat dan politik, menyangkut minat dan perhatian seseorang terhadap lingkungan serta politik tempat dia hidup. Kemudian melihat tahap pemilu yanag memasuki masa kampanye, partisipasi politik tanpa kesadaran politik itu bisa saja terjadi.

Hal ini senada dengan hasil wawancar dengan salah seorang nelayan yakni, saudara Jumaidi mengatakan : 
"Saya dalam pilpres kali ini pernah ikut dalam salah satu kampanye calon, dimana saya ikut karena pada saat itu saya tidak ada kegiatan. Namun pada saat pemilihan berlansung saya tidak pergi ke TPS. (Hasil wawancara dengan Jumaidi tanggal 13 Agustus 2019)".

Dari hasil wawancara di atas, kedua narasumber dapat di katakana memiliki kesadaran politik yang sama-sama rendah. Rendahnya partisipasi di sebabkan karena minimnya pengetahuan terkait politik dan pemilu. Politik dianggap sebagai sebuah proses dimana pelaku politik saling menjatuhkan satu sama lain. Kesadaran politik harus di bentuk sedini mungkin, sebab kesadaran politik menjurus kedalam pewarisan sistem politik yang baik.

Penanaman kesadaran politik harus dilakukan disemua lapisan masyarakat. Hal ini dikarenakan pemilih pemula rentan dan cenderung dimobilisasi oleh lingkungan sekitar dengan cara ditanamkan kebiasaan politis yang bersifat pragmatis dan sesaat serta menumpulkan daya kritis untuk lebih visioner dan selektif dalam memilih pemimpin. Selain itu, sosialisasi politik yang maksimal akan turut membentuk kesadaran politik itu sendiri.

\section{2) Kepercayaan Kepada Pemerintah Rendah}

Kepercayaan terhadap pemerintah dapat di katakana sebagai penilaian masyarakat terhadap pemerintah apakah ia menilai pemerintah dapat di percaya dan dapat di pengaruhi atau tidak, baik dalam pembuatan kebijakan-kebijakan atau pelaksanaan pemerintahan. Rendahnya tingkat kepercayaan publik terhadap pemerintah dalam dalam pendidikan politik di kota mataram mengakibatkan lemahnya kepercayaan masyarakat terhadap lembaga pemerintah.

Menurut salah seorang pemilih pemula yakni, saudara Rifkil Hafis mengatakan :

"Tingkat kepercayaan saya rendah kepada pemerintah, faktor yang menyebabkan saya mengalami krisis kepercayaan kepada pemerintah adalah, asumsi bahwa seorang politisi itu identink dengan orang yang tak bisa di percaya dan selalu ingkar janji (hasil wawancara dengan Rifkil Hafis tanggal 12 Agustus 2019)".

Berdasarkan kedua hasil wawancara tersebut, rendahnya tingkat kepercayaan masyarakat kepada pemerintah disebabkan karena ketidak konsistenannya pemerintah atau elit politik terhadap janji-janji politik dan program-program kerja yang telah dirumuskan ketika menjadi calon. Selain itu faktor yang mempengaruhi rendahnya kepercayaan masyarakat kepada pemerintah adalah perilakuperilaku pemerintah yang sering menyalahgunakan wewenang dan kekuasaanya. Hal ini menimbulkan trauma politik yang berkepanjangan yang dialami oleh masyarakat itu sendiri.

\section{c. Hasil Pendukung Model Partisipasi}

Sebagai data pendukung, peneliti akan menyajikan data model partisipasi pemilih, antara partisipasi aktif dan partisipasi apatis yang berasal dari hasil wawancara dengan narasumber. Dimana dalam kali ini, narasumber di kategorikan berdasarkan empat strata sosial sebagai data yang diantaranya adalah masyarakat berstrata sosial nelayan, pemilih pemula, akademisi, dan masyarakat yang berpropesi sebagai wiraswasta.

Peneliti telah melakukan wawancara dengan hasil seperti yang di sajikan dalam pembahasan sebelumnya. Maksud peneliti membuat bagian ini adalah agar penyajian data hasil dapat di pahami dengan mudah oleh pembaca dan peneliti dapat memfokuskan hasil dari penelitian yang telah di lakukan. Berikut adalah tabel hasil wawancara yang dibuat berdasarkan aktif atau apatisnya pemilih di Kota Mataram pada Pemilu Presiden dan Wakil Presiden 2019 : 
Tabel. 4.7

Model Partisipasi Pemilih Kota Mataram Berdasarkan Hasil Keseluruhan Wawancara

\begin{tabular}{|c|c|c|c|c|c|}
\hline \multirow{2}{*}{ No } & \multirow{2}{*}{ Nama } & \multirow{2}{*}{ Kecamatan } & \multirow{2}{*}{ Strata Sosial } & \multicolumn{2}{|c|}{$\begin{array}{c}\text { Model } \\
\text { Partisipasi }\end{array}$} \\
\hline & & & & $\begin{array}{c}\text { Akti } \\
\text { f }\end{array}$ & Apatis \\
\hline 1 & $\begin{array}{l}\text { Jaya } \\
\text { Kusum } \\
\text { a }\end{array}$ & Selaparang & Akademisi & $\checkmark$ & \\
\hline 2 & Jahman & Ampenan & Nelayan & $\checkmark$ & \\
\hline 3 & $\begin{array}{l}\text { Ahmad } \\
\text { Fatoni }\end{array}$ & Cakranegara & Wiraswasta & $\checkmark$ & \\
\hline 4 & $\begin{array}{l}\text { Giri } \\
\text { Buya }\end{array}$ & Selaparang & Akademisi & $\checkmark$ & \\
\hline 5 & $\begin{array}{l}\text { Baiq } \\
\text { Fani } \\
\text { Suhada }\end{array}$ & Ampenan & $\begin{array}{l}\text { Pemilih } \\
\text { Pemula }\end{array}$ & $\checkmark$ & \\
\hline 6 & $\begin{array}{l}\text { Aldi } \\
\text { Elang }\end{array}$ & Sandubaya & $\begin{array}{l}\text { Pemilih } \\
\text { Pemula }\end{array}$ & & $\checkmark$ \\
\hline 7 & Jumaidi & Ampenan & Nelayan & & $\checkmark$ \\
\hline 8 & $\begin{array}{l}\text { Muham } \\
\text { mad } \\
\text { Kasim }\end{array}$ & Sekarbela & Wiraswasta & $\checkmark$ & \\
\hline 9 & $\begin{array}{l}\text { Rifkil } \\
\text { Hafis }\end{array}$ & Sekarbela & $\begin{array}{l}\text { Pemilih } \\
\text { Pemula }\end{array}$ & & $\checkmark$ \\
\hline 10 & $\begin{array}{l}\text { Munira } \\
\mathrm{h}\end{array}$ & Mataram & Wiraswasta & & $\checkmark$ \\
\hline \multicolumn{4}{|c|}{ Presentase } & $60 \%$ & $40 \%$ \\
\hline
\end{tabular}

Sumber: Data Diolah Peneliti 2019

Dari tabel tersebut, jumlah presentase untuk partisipasi aktif jauh lebih tinggi dari partisipasi apatis, dengan jumlah presentase $60 \%$ berbanding $40 \%$. Dengan presentase ini bisa dikatakan bahwa partisipasi pemilih di Kota Mataram pada pemilu Presiden dan Wakil Presiden Tahun 2019 tergolong pada model partisipasi aktif.

Data terkait partisipasi aktif di dominasi oleh masyarakat berstrata sosial akademisi, dari dua hasil wawancara akademisi lebih condong masuk kedalam model partisipasi aktif. Sedangkan untuk masyarakat berstrata sosial nelayan, pemilih pemula dan wiraswasta ada beberapa yang masuk kedalam model partisipasi apatis berdasarkan hasil dari wawancara.

Analisis peneliti terkait partisipasi masyarakat Kota Mataram dapat di pengaruhi oleh lingkungan tempat tinggal beserta strata sosial dari pemilih. Kedua kategori ini seringkali muncul dalam wawancara dengan narasumber seperti wawancara dengan saudara Jahman, dimana dalam hal ini ia tingginya kesadaran politknya akan dapat di pengaruhi oleh profesi yang sedang di geluti. Selain itu, track record seorang pemimpin yang di perlihaatnya akan mempengaruhi partisipasi seorang pemilih.

\section{KESIMPULAN}

Dari uraian yang telah di paparkan dapat diambil kesimpulan mengenai partisipasi pemilih pada pilpres 2019 di Kota Mataram. Adapun kesimpulan sebagai berikut:

a. Jumlah Partisipasi Masyarakat Kota Mataram

Dari 278.358 jumlah DPT yang di miliki KPUD Kota Mataram pada pilpres 2019, jumlah partisipasi masyarakat Kota Mataram sampai pada angka 222.687 pemilih. Hasil ini dapat dilihat pada tabel 4.5 dimana dari masingmasing kecamatan, kecamatan Ampenan memiliki tingkat partisipasi tertinggi berjumlah 49.134 pemilih dari 57.202 jumlah pemilih yang terdaftar di DPT.

b. Model Partisipasi Pemilih di Kota Mataram

Jika melihat pembagian model partisipasi pemilih antara partisipasi aktif dan partisipasi apatis, masyarakat Kota Mataram termasuk kedalam pemilih berpartisipasi aktif. Dimana dengan jumlah presentase dari tabel 4.7 menyatakan bahwa tingkat partisipasi aktif pemilih di Kota Mataram mencapai 60\%. Sedangkan untuk masyarakat berpartisipasi apatis hanya mencapai $40 \%$ dari jumlah 10 sampel atau narasumber yang telah di pilih dengan cermat agar relevan dengan struktur penelitian.

\section{SARAN}

Pemilihan Umum pada dasarnya adalah urusan kepercayaan masyarakat terhadap pemerintah, sangat diharapkan agar pemerintah dan partai politik dapat meningkatkan derajat kepercayaan masyarakat terhadap proses politik. Proses politik yang terjadi pada pilpres 2019 di Kota Mataram memiliki alasan tersendiri kenapa tingkat partisipasi masyarakat tidak sepenuhnya dapat ikut berpartisipasi secara aktif, bahkan tidak ingin berpartisipasi dikarenakan lelah dengan janji-janji politik dan program pemerintah yang tidak tepat sasaran. Masyarakat menilai proses pemilu hanya sebagai ajang perebut kekuasaan dan hanya mencedrai proses demokrasi, sehingga sebagian kecil masyarakat menilai tidak penting ikut berpartisipasi secara aktif dalam pilpres 2019.

Berikut adalah saran dari peneliti :

a. masyarakat kota mataram, sangat penting untuk ikut berpartisipasi dalam 
penyelenggaran pemilu, agar hak-hak sebagai warga Negara dapat tersalurkan.

Penyelenggara dan pelaku politik harusnya memberikan pendidikan politik yang baik untuk masyarakat kota mataram. Dimana dengan pendidikan politik yang baik, kesadaran politik masyarakat akan meningkat dan akan memperbaiki sistem demokrasi yang tidak sehat. Sangat di harapkan penyelengara tetap netral dengan posisinya, pelaku politik tetap sehat dalam melakukan kampanye dan pembentukan strategi lainnya untuk memenagkan kandidat masing-masing agar pelaksanaan pesta demokrasi dalam hal ini pemilu Presiden dan Wakil Presiden tetap memiliki partisipasi aktif masyarakat yang tetap tinggi. Harapan kita untuk kedepan, semua element yang tergabung dalam Negara bisa saling merangkul dan saling mempercayai untuk demokrasi yang telah kita sepakati

DAFTAR PUSTAKA (12pt)

Abdullah, Rozali. (2009). Mewujudkan Pemilu Yang Lebih Berkualitas. Jakarta: Rajawali Pers.

Amirudin, Zaini, A. B. (2006). Pilkada Lansung, Problem dan Prospek. Yogyakarta : Pustaka Pelajar.

Budiardjo, Mariam. (2009). Dasar-Dasar Ilmu Politik. Jakarta: Gramedia.

Efriza. (2012). Political Explore. Bandung: CV. Alfabeta.

Faisal, Andi. (2016). Literasi Politik dan Pelembagaan Pemilu. Jakarta.Fikom UP Press.

Fred Isjwara,SH,LMM. Pengantar Ilmu Politik. Cetakan Ke-5 (Cetakan Ke-1 1964). Binacipta. Bandung. 1974.

Gaffar, Afan. (2004). Politik Indonesia Transisi Menuju Demokrasi. Yogyakarta: Pustaka Pelajar 2000.

Gaffar, Janedjri. (2012). Politik Hukum Pemilu. Jakarta: Konstitusi Perss.

Haryono, Dwi. (2016). Strategi KPU Dalam Meningkatkan Partisipasi Pemilih Pada Pemilihan Walikota dan Wakil Walikota Samarinda Tahun 2015.
Samarinda. eJournal Administrativ Refom.

Kuncoro, Wahyu. (2018). Media Sosial,Trust, dan Partisipasi Politik Pada Pemilih Pemula. Yogyakarta.

Mukarom, Zainal. (2008). Perempuan dan Politik : Studi Komunikasi Politik Tentang Keterwakilan Perempuan di Legislatif. Bandung. Mediator.

Putra, Arie. (2014). Partisipasi Politik Anak Muda di Pekanbaru,Jakarta, Cirebon, Palu, dan Jayapura. Jakarta. DEMOS.

Surbakti, Ramlan. (1999). Memahami Ilmu Politik. Jakarta: Gramedia.

Dokumen :

Undang-Undang Dasar Tahun 1945. Undangundang Nomor 15 tahun 2011 tentang Penyelenggara Pemilihan Umum 